\title{
Ecology of a novel Synechococcus clade occurring in dense populations in saline Antarctic lakes
}

\author{
L. M. Powell ${ }^{1}$, J. P. Bowman ${ }^{1, *}$, J. H. Skerratt ${ }^{2}$, P. D. Franzmann ${ }^{3}$, H. R. Burton ${ }^{4}$ \\ ${ }^{1}$ Australian Food Safety Centre for Excellence, School of Agricultural Science, University of Tasmania, Private Bag 54, \\ Hobart, Tasmania 7001, Australia \\ ${ }^{2}$ CSIRO Marine Research Division, Castray Esplanade, Hobart, Tasmania 7001, Australia \\ ${ }^{3}$ CSIRO Land and Water Division, Underwood Avenue, Floreat Park, Perth, Western Australia 6014, Australia \\ ${ }^{4}$ Australian Antarctic Division, Channel Highway, Kingston, Tasmania 7050, Australia
}

\begin{abstract}
The seasonal distribution and abundance of Synechococcus-like morphotypes was investigated in meromictic lakes and coastal areas of the Vestfold Hills, Antarctica. Populations were monitored by flow cytometry utilising phycoerythrin content and small cell size to distinguish the cells from other phytoplankton. In Ace Lake, the Synechococcus bloom commenced in September at the water temperature minimum and peaked in late November. Populations (up to $8 \times 10^{6}$ cells ml $^{-1}$ ) were maximally stratified at a depth of $11 \mathrm{~m}$, corresponding to waters which were supersaturated with oxygen, high in phosphate and which received $>5 \mu \mathrm{mol}$ photons $\mathrm{m}^{-2} \mathrm{~s}^{-1}$ of light. At this depth, salinity $\left(30 \mathrm{~g} \mathrm{~kg}^{-1}\right)$ was constant throughout the year and temperature ranged from $4.5^{\circ} \mathrm{C}$ in October to $10.5^{\circ} \mathrm{C}$ in February. In late November, high numbers of Synechococcus cells also occurred in the moderate salinity water bodies Lake Abraxas and Pendant Lake (salinity 16.5 to $31.0 \mathrm{~g} \mathrm{~kg}^{-1}$ ), with populations highly stratified in Lake Abraxas (up to $1.5 \times 10^{7}$ cells ml ${ }^{-1}$, temperature $8.0^{\circ} \mathrm{C}_{\text {, salinity }}$ $20.3 \mathrm{~g} \mathrm{~kg}^{-1}$ ) but less so in the colder waters of Pendant Lake (max. $1.5 \times 10^{7} \mathrm{cells} \mathrm{ml}^{-1}$, temperature 0.1 to $1.1^{\circ} \mathrm{C}$, salinity $31.0 \mathrm{~g} \mathrm{~kg}^{-1}$ ). Synechococcus populations did not occur in brackish, coastal marine or hypersaline water bodies in the Vestfold Hills. Populations appear to be controlled primarily by temperature and to a lesser extent by light availability and grazing. Characterization of non-axenic cultures indicated that the Antarctic lake Synechococcus populations were similar to other polar picocyanobacteria in terms of cardinal growth temperatures (minimum, optimum, maximum: $T_{\min }-17.0^{\circ} \mathrm{C}, T_{\text {opt }} 19.8^{\circ} \mathrm{C}, T_{\max } 29.5^{\circ} \mathrm{C}$ ) and slow growth. Related only peripherally to Synechococcus sp. Cluster 5.2 (Marine Cluster B), the Antarctic strains represent a unique and highly adapted clade in the stable water columns of some saline Antarctic lakes.
\end{abstract}

KEY WORDS: Synechococcus $\cdot$ Antarctica $\cdot$ Meromictic lakes $\cdot$ Marine ecosystems Resale or republication not permitted without written consent of the publisher

\section{INTRODUCTION}

The contribution of picocyanobacteria to biomass and primary production in marine waters is highly variable, but follows certain general patterns. Marine Synechococcus and Prochlorococcus spp. make relatively large contributions to primary production in oligotrophic open ocean waters. Populations occur down to the deep chlorophyll maximum (Waterbury 1992); however, vertical distribution patterns appear extremely variable. In the tropical oceans, picocyano- bacteria contribute as much as $50 \%$ to the primary production, but this dramatically decreases in the polar regions, where small eukaryotic phytoplankters dominate (Gradinger \& Lenz 1995). Populations vary from $10^{2}$ cells ml ${ }^{-1}$ or less in polar seas (Marchant et al. 1987)

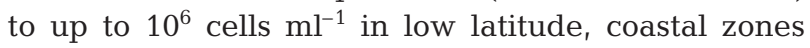
(Agawin et al. 2003). Synechococcus-like picocyanobacteria also can occur in transitional and freshwater ecosystems including meromictic lakes, and populations can sometimes reach high levels, especially if eutrophic (Hawes 1990, Maeda et al 1992). Clear 
similarities in the distribution and ecological responses have been observed for picocyanobacteria in Arctic and Antarctic freshwater bodies (Vezina \& Vincent 1997). Temperature appears to be a major limiting factor for polar ocean picocyanobacterial abundance (Wilmotte et al. 2002). Light, nutrients, salinity, grazing pressure and viral lysis also all play a role to varying extents in controlling Synechococcus populations (Waterbury 1992, Bertrand \& Vincent 1994, Mackey et al. 2002, Moore et al. 2002, Sullivan et al. 2003, Larsen et al. 2004).

The genus Synechococcus currently includes a series of polyphyletic lineages within the phylum Cyanobacteria (Herdman et al. 2001, Scanlan \& West 2002, Fuller et al. 2003). A substantial proportion of marine Synechococcus spp. cluster with Prochlorococcus spp. as a distinct clade containing various subgroups (Rocap et al. 2002, Fuller et al. 2003), e.g. Synechococcus Group 5.1 (Marine Cluster A) and Group 5.2 (Marine Cluster B). Characteristics that are used to categorize Synechococcus spp. such as photosynthetic pigmentation, salinity and nitrogen requirements and motility (Herdman et al. 2001), vary considerably within these and other clades (Rocap et al. 2002, Fuller et al. 2003), indicating that only closely related strains share the same ecotypic and physiological adaptations (Casamayor et al. 2002, Ernst et al. 2003). Much the same pattern of phenotypic variability occurs within various groups of the Bacteria in general, indicating that niche adaptation can often be sub-specific (Cohan 2002). This is certainly the case for picocyanobacteria, with comparisons of phylogenetically conserved genes revealing genetic variability and niche specialisation, as demonstrated by substantial divergences in genomes even amongst strains that show close relationships (Rocap et al. 2003).

In the Southern Ocean, genetic analysis of seawater down to $54^{\circ} \mathrm{S}$ revealed Synechococcus strains related to strains of Group 5.1, which are also common in temperate oceanic zones (Wilmotte et al. 2002). No specific data on Synechococcus in Antarctic zone waters is available. Sequences obtained from the bottom sediment of various Vestfold Hills water bodies grouped in the Synechococcus/Prochlorococcus clade (Bowman et al. 2000). Other evidence for the presence of Synechococcus in these lakes also comes indirectly from the occurrence of sediment glycolipid compounds specific only to cyanobacteria (Damsté et al. 2001). Various marine salinity lakes of the Vestfold Hills, Eastern Antarctica (Rankin et al. 1997, Vincent et al. 2000) were found to contain rich blooms of phycoerythrincontaining picocyanobacteria. Populations were 1 to 3 orders of magnitude higher than typically found in other marine water bodies (Waterbury 1992) or other polar lakes thought to be dominated by cold-adapted cyanobacteria (Tang et al. 1997, Vezina \& Vincent 1997, Vincent et al. 2000). This prompted more detailed study of these cyanobacteria, with the primary study site located at Ace Lake, a well-studied meromictic lake in the Vestfold Hills (Gibson 1999). Ace Lake has 3 stratified zones: (1) a top mixed zone; (2) below this a layer supersaturated with oxygen separated by a pycnocline (depth 7 to $9 \mathrm{~m}$ ); (3) a bottom zone below another pycnocline (depth 12 to $15 \mathrm{~m}$ ), which is anoxic and contains high methane levels but is sulphate-depleted. The ratio of major cations and anions are very similar to that of seawater (Franzmann 1996). The characteristics of these populations are investigated here in detail in order to determine the factors leading to their high density and to determine aspects of their ecology, physiology and phylogeny.

\section{MATERIALS AND METHODS}

Samples. Water samples were collected from various lakes and coastal waters using a Kemmerer water sampler (Geneq) (see Table 1). For the seasonal study of Ace Lake, samples were collected monthly between February and August 1992 and then fortnightly between September 1992 and January 1993. Samples were kept at $4^{\circ} \mathrm{C}$ and flow cytometry analysis was conducted within $4 \mathrm{~h}$ of sampling. Subsamples were fixed in $1.5 \%$ (vol./vol.) formalin for epifluorescence microscopy. Photosynthetically available radiance (PAR) within the lakes was determined using a digital scalar irradiance meter and measurements were taken as close to the solar noon as possible. The euphotic depth values were calculated from incident light readings (Kirk 1994).

Water chemistry. A submersible data logger was used to collect temperature and conductivity data. Dissolved organic carbon (DOC) was analysed from filter samples using a SK12 DOC analyser (Skalar). Soluble reactive phosphate (SRP) and nitrate were analysed using an Alkem Flow Solution Autoanalyser. Detection limits for SRP and nitrate were 0.04 and $0.02 \mu \mathrm{M}$, respectively.

Flow cytometry. Cell counts for Synechococcus and phototrophic nanoplankton were conducted using a FACScan flow cytometer (Becton Dickinson), fitted with an argon laser with a $488 \mathrm{~nm}$ emission. Cell populations were detected using combinations of forward light scatter, side-angle light scatter, green, orange and red fluorescence emission using a 585/42 $\mathrm{nm}$ band-pass filter for phycoerythrin and propidium iodide-containing cells, and a $650 \mathrm{~nm}$ long-pass filter for chlorophyll a-containing cells. The instrument was set with a red or green fluorescence threshold and a 
low acquisition rate. Microspheres of $1.98 \mu \mathrm{m}$ diameter (Polysciences) were used for calibration for the determination of cell sizes and concentrations. Populations were gated on 2-parameter dot-plots using FACScan software. Non-photosynthetic bacterial populations were determined by staining with propidium iodide. Samples were centrifuged at $6000 \times g$ at $4^{\circ} \mathrm{C}$ for $30 \mathrm{~min}$, and the supernatant decanted. The sedimented cells were then washed $\left(6000 \times g, 4^{\circ} \mathrm{C}, 10 \mathrm{~min}\right)$ once with phosphate-buffered saline (PBS; $130 \mathrm{mM}$ $\mathrm{NaCl}, 7 \mathrm{mM} \mathrm{Na} \mathrm{HPO}_{4}, 3 \mathrm{mM} \mathrm{NaH} \mathrm{PO}_{4} ; \mathrm{pH}$ 7.0) and resuspended in $90 \mu \mathrm{l}$ of PBS. Propidium iodide was then added to a final concentration of $7 \mu \mathrm{g} \mathrm{ml}^{-1}$ and the suspension was incubated overnight at $4^{\circ} \mathrm{C}$. Following incubation, the samples were washed twice with PBS and then resuspended in a known volume of PBS. Microspheres were used for size calibration as indicated above. Bacterial cells were then analysed by flow cytometry by comparing the cell-to-bead ratio. Cell count data where required was subjected to ANOVA and pair-wise multiple comparison procedures (Student-Newman-Keuls tests) using the SAS program (SAS Institute).

Isolation of cultures. Lake samples were taken from depths at which concentrations of Synechococcus cells were maximal (Lake Abraxas: 19 m, Ace Lake: $11 \mathrm{~m}$, Pendant: $6 \mathrm{~m}$ ) and were enriched in SNAX and SOX media (Waterbury 1992) with incubation at 4 to $10^{\circ} \mathrm{C}$ on a $12 \mathrm{~h}$ dark/light cycle at $20 \mu \mathrm{mol}$ photons $\mathrm{m}^{-2} \mathrm{~s}^{-1}$. The SNAX medium was prepared as an autoclave-sterilised $10 \times$ stock solution consisting of $750 \mathrm{mg} \mathrm{NaNO}, 53 \mathrm{mg} \mathrm{NH} \mathrm{Nl}_{4}, 15 \mathrm{mg} \mathrm{K} \mathrm{HPO}_{4}, 10 \mathrm{mg}$ $\mathrm{Na}_{2} \mathrm{CO}_{3}, 5 \mathrm{mg}$ and $1 \mathrm{ml}$ of micronutrients in $100 \mathrm{ml}$ deionized water. The $100 \mathrm{ml}$ stock solution was added to $250 \mathrm{ml}$ of deionized water and $750 \mathrm{ml}$ of Ace Lake water. The SOX medium consisted of the same constituents as the SNAX medium except that $\mathrm{NaNO}_{3}$ and $\mathrm{NH}_{4} \mathrm{Cl}$ were omitted. The autoclavesterilised micronutrient solution consisted of $1.4 \mathrm{~g}$ $\mathrm{MnCl}_{2} \cdot 4 \mathrm{H}_{2} \mathrm{O}, 0.22 \mathrm{~g} \mathrm{ZnSO} \cdot 7 \mathrm{H}_{2} \mathrm{O}, 0.39 \mathrm{~g} \mathrm{NaMoO}_{4}$. $2 \mathrm{H}_{2} \mathrm{O}, \mathrm{Co}\left(\mathrm{NO}_{3}\right)_{2} \cdot 6 \mathrm{H}_{2} \mathrm{O}, 6.25 \mathrm{~g}$ citric acid hydrate and $6 \mathrm{~g}$ ferric ammonium citrate in $1000 \mathrm{ml}$ deionized water. Ace Lake water was collected from a depth of $11 \mathrm{~m}$ and filtered through a $0.2 \mu \mathrm{m}$ filter and stored at $4^{\circ} \mathrm{C}$ in the dark in a sterile container. Media used were also prepared with seawater collected just off Tasmania (Tasman Peninsula) and open Southern Ocean water and filtered and stored in the same way. Enrichments were also performed in modified $f / 2$ medium and FE medium, which consisted of $f / 2$ medium containing $30 \mathrm{~g} \mathrm{l}^{-1}$ disodium EDTA. f/2 medium consisted of $0.1 \mathrm{ml}$ of autoclave sterilised stock solutions of $\mathrm{NaNO}_{3}\left(150 \mathrm{~g} \mathrm{l}^{-1}\right), \mathrm{NaH}_{2} \mathrm{PO}_{4} \cdot 2 \mathrm{H}_{2} \mathrm{O}\left(10 \mathrm{~g} \mathrm{l}^{-1}\right)$ and trace element solution (as above) and $0.05 \mathrm{ml}$ vitamin solution added to $1000 \mathrm{ml}$ Ace Lake water.
The filter-sterilised vitamin solution contained $0.4 \mathrm{~g} \mathrm{l}^{-1}$ thiamine hydrochloride, $2 \mathrm{mg} \mathrm{l}^{-1}$ biotin and $2 \mathrm{mg} \mathrm{l}^{-1}$ cyanocobalamin. Non-axenic cultures were obtained by serial dilution in SNAX medium containing $10 \mathrm{mg}$ $\mathrm{l}^{-1}$ cycloheximide (Sigma) to remove contaminating cryptomonads and diatoms.

Antibiotics, comprising a mixture of 4 to $8 \mathrm{mg} \mathrm{ml}^{-1}$ penicillin, 4 to $8 \mathrm{mg} \mathrm{ml}^{-1}$ streptomycin and 0.4 to $0.8 \mathrm{mg} \mathrm{ml}^{-1}$ chloramphenicol and (separately) imipenem at 200 to $400 \mathrm{mg} \mathrm{l}^{-1}$ were added to Synechococcus cultures and incubated in the dark at $20^{\circ} \mathrm{C}$ for $40 \mathrm{~h}$. Following incubation, Synechococcus cells were washed in SNAX to remove antibiotics and the cells were resuspended in SNAX medium and allowed to recover and grow under light. Although heterotrophic bacterial populations were suppressed in the cultures, the cultures were not successfully rendered axenic. The non-axenic cultures obtained were deposited at the CSIRO Algal Culture Collection.

Cell counts and morphological analyses. Cell counts and morphological characterization were performed with an epifluorescence microscopy using a Leitz DMRBE microscope (Leica Microsystems). Slides of picocyanobacterial cultures or lake water samples were filtered through $0.2 \mu \mathrm{m}$ polycarbonate filters stained with Irgalan Black (Millipore). Bacteria in $1 \%$ (vol/vol) formalin-fixed samples in PBS were stained with DAPI at $2.5 \mu \mathrm{g} \mathrm{ml}^{-1}$ overnight at $4^{\circ} \mathrm{C}$, and were then collected on $0.2 \mu \mathrm{m}$ black filters, dried and mounted on glass slides with immersion oil and inspected using epifluorescence microscopy under blue light. Cell sizes were determined with the aid of eyepiece micrometers.

Phytoplanktonic surface area in Ace Lake samples was determined by microscopy and flow cytometry. The total surface area per unit volume contributed by large phytoplankters (Mesodinium rubrum, Cryptomonas sp. and Pyraminomas gelidicola) were determined by counting and measuring the size of these cells in samples preserved in Lugol's iodine, using an inverted microscope fitted with a stage micrometer. The surface area contributed by Synechococcus and phototrophic nanoplankton was analysed by flow cytometry (as indicated above). Surface area was computed by multiplying mean cell number for a fixed volume by the mean cell size.

Transmission electron microscopy of cultures used cells fixed with $4 \%$ (vol/vol) glutaraldehyde, post-fixed with $2 \%$ (wt/vol) $\mathrm{OsO}_{4}$, and dehydrated with a series of acetone:water washes from $10 \%$ acetone (vol/vol) up to $100 \%$ acetone. Cells were then suspended in Spurr's resin. Serial thin-sections were cut with a microtome and stained with uranyl acetate or lead citrate and examined under a JOEL 1200 EX transmission electron microscope. 
Pigment analysis. Dense culture suspensions were examined over wavelengths of 400 to $750 \mathrm{~nm}$ using a GBC916 UV/VIS spectrophotometer (Dandenong) fitted with an integrating sphere. In vivo emission spectra were obtained between 500 and $700 \mathrm{~nm}$ with an excitation wavelength of $450 \mathrm{~nm}$, while excitation spectra were collected over 400 to $665 \mathrm{~nm}$ with an emission wavelength of $680 \mathrm{~nm}$. Lipid-soluble pigments in lake samples and cultures were extracted and analysed using an HPLC (Spectraphysics) fitted with a Spectra Focus detector, Spherisorb OD52 $250 \times 4.6 \mathrm{~mm}$ column and a Gilson 231 autosampler (samples were maintained at $-10^{\circ} \mathrm{C}$ ), using the ternary gradient system as described by Wright et al. (1991). Profiles obtained were compared with profiles from algal cultures with chemically well-defined pigments including Amphidinium carterae, Chroomonas salina, Dunaliella tertiolecta, Micromonas pusilla, Pavlova lutheri, Porphyridium cruentum, Pycnococcus provasolii and Synechococcus sp. Strain WH 7803 (Waterbury 1992).

Lipid analysis. Lipids from exponential phase cultures were extracted by the modified 1-phase chloroform-methanol-water Bligh Dyer method (White et al. 1979). Lipid classes were quantified from the lipid extracts using an Iatroscan Kk. III TH-10 thin-layer chromatography-flame ionisation detector (Iatron, Japan) and using hexane:methyl ether:ethanol (60:17:0.5 ratio) as the carrier solvent. A portion of the crude lipid extract was saponified and converted to the corresponding fatty acid methyl esters and identified by gas chromatography and mass spectrometry as previously described by Nichols et al. (1991) and Skerratt et al. (1991).

16S rRNA gene sequencing. High molecular weight DNA was extracted from cell biomass using the Marmur method (Marmur \& Doty 1962). PCR amplification of 16S rRNA genes used published primers 8-28f (5'-AGA GTT TGA TCC TGG CTC AG-3') and 15221542r (5'-AAG GAG GTG ATC CAG CCG CA-3') as previously described (Bowman et al. 1997). PCR products were purified from agarose electrophoresis gels using the QIA quick gel extraction kit (Qiagen). The purified PCR product was nearly completely sequenced using the BigDye Version 1.1 terminator cycle sequencing kit using 16S rRNA gene primers 8-28f, 1522-1542r, 684-704f (5'-GTA GCG GTG AAA TGC GTA GA), 785-765r (5'-TCT ACG CAT TTC ACC GCT AC-3'), 908-928f (5'-AAA CTC AAA GGA ATT GAC GG-3') and 518-536f (5'-CAG CAG CCG CGG TAA TAC-3'), and sequence reactions were subsequently electrophoresed and analysed using the ABI 373A automated DNA sequencer (Applied Biosystems). Sequence data was checked in BioEdit v. 6.0.6. (Hall 1999), and sequences from the GenBank nucleotide library closely matching the Antarctic strain sequences were downloaded and aligned manually. The sequence data set was analysed using the Phylip program package (Felsenstein 1993) with maximum-likelihood distances determined using DNADIST and the phylogenetic tree constructed using the neighbour-joining procedure with NEIGHBOR. Bootstrap analysis was performed using 500 replicates using the program SEQBOOT and CONSENSE.

DNA base composition and DNA:DNA hybridisation. The DNA base composition was determined by the thermal denaturation procedure (Sly et al. 1986), using a GBC916 UV/VIS spectrophotometer fitted with a temperature controller. Pseudoalteromonas haloplanktis (mol\% G + C 41.0) and Escherichia coli Strain K12 (mol\% G + C 52.0) were used as reference standards. DNA:DNA hybridisation of genomic DNA between the 3 Antarctic lake strains was performed using the spectrophotometric renaturation kinetics technique as modified by Bowman et al. (1998). Briefly, genomic DNA at approximately $100 \mathrm{\mu g} \mathrm{ml}^{-1}$ was sheared to an average size of $1 \mathrm{~kb}$ using sonication and then dialysed at $4^{\circ} \mathrm{C}$ against SSC buffer $(0.15 \mathrm{M} \mathrm{NaCl}$ and $0.015 \mathrm{M}$ trisodium citrate, $\mathrm{pH}$ 7.0). The sheared DNA at 75 to $80 \mu \mathrm{g} \mathrm{ml}^{-1}$ from 2 strains were mixed in equal proportions and measured in comparison to separate unmixed controls of the same strains. The DNA was denatured at $95^{\circ} \mathrm{C}$ for $5 \mathrm{~min}$ in cuvettes in a GBC 916 UV/VIS spectrophotometer with a temperature controller. Following stabilisation of the absorbance, $20 \times \mathrm{SSC}$ (preheated to $90^{\circ} \mathrm{C}$ ) was quickly added and mixed to increase the salinity of the solution to that of $2 \times$ SSC. The temperature was adjusted to $71^{\circ} \mathrm{C}$, the optimal temperature for renaturation for the Antarctic lake Synechococcus strains, assuming an average G + $\mathrm{C}$ of $56.5 \mathrm{~mol} \%$. The linear decline in absorbance at $260 \mathrm{~nm}$ was then monitored for $40 \mathrm{~min}$. The percent DNA hybridisation was determined from the renaturation rate using the equation:

$\%$ DNA hybridisation $=4 A B-A-B / \sqrt{ } 2(A \times B) \times 100 \%$

where $A B$ is the renaturation rate for equal mixtures of DNA of the strains compared, and $A$ and $B$ are the rates for the unmixed controls of the respective strains. Values below $25 \%$ are considered insignificant due to random background renaturation. We performed 4 to 5 replicate analyses for each strain pair compared.

Physiological characterisation. Duplicate cultures were grown at -1 to $30^{\circ} \mathrm{C}$ under $20 \mu \mathrm{mol}$ photons $\mathrm{m}^{-2}$ $\mathrm{s}^{-1}$ on a $12 \mathrm{~h}$ dark/light cycle in a temperature gradient incubator (Toyo). Aseptically collected subsamples were taken periodically from the cultures and analysed by flow cytometry (as above) to determine cell numbers. Growth rates and cardinal temperatures (minimum, $T_{\min }$ optimum, $T_{\text {opti }}$ maximum, $T_{\max }$ ) were predicted using the 4-parameter square-root growth 
kinetic model of Ratkowsky et al. (1983). The SAS statistical program (SAS Institute) was used to fit the model to the data and to determine the upper and lower root mean-square error (RMSE) limits for the model. The effect of light (tested between 5 and $300 \mu \mathrm{mol}$ photon $\mathrm{m}^{-2} \mathrm{~s}^{-1}$ ) on growth was tested at $15^{\circ} \mathrm{C}$ using SNAX media with light monitored using a Li-Cor model Li185 Quantum Ratiometer/Photometer (Li-Cor). The effect of salinity was tested in the SNAX medium prepared with dilutions of Ace Lake water in distilled water and with added sea salts (Sigma). Flow-cytometry was used to monitor growth over time as described above.

In situ growth experiments. The metabolic inhibitor procedure (Xiuren \& Vaulot 1992) was used to assess environmental parameters on growth rates in Ace Lake during summer. Grazing pressure and effects of light, salinity, nutrients and temperature on growth rates were tested in combination using a factorial design (Campbell \& Carpenter 1986).

For grazing pressure experiments, cycloheximide was added at $100 \mathrm{\mu g} \mathrm{ml}^{-1}$ and was used to inhibit eukaryotic grazers, while ampicillin at $0.03 \mu \mathrm{g} \mathrm{ml}^{-1}$ was used to inhibit growth of Synechococcus. At this concentration, ampicillin caused slight decreases in cell concentration, possibly due to cell lysis. Controls were also included which either contained no antibiotics or cycloheximide $\left(100 \mu \mathrm{g} \mathrm{m}^{-1}\right)$ and ampicillin $\left(10 \mu \mathrm{gll}^{-1}\right)$.

Ace Lake water samples used in the experiments were collected from a depth of $6 \mathrm{~m}$ using a Kemmerer water sampler and added to plastic sample bags ('Whirl Pacs'). To assess the affects of temperature, the bags were lowered to 3 different depths $(6,8$ or $10 \mathrm{~m})$ in Ace Lake. Temperatures at each depth over the course of the experiment were quite stable: 3.0 to $3.4^{\circ} \mathrm{C}$ at $6 \mathrm{~m}, 6.3^{\circ} \mathrm{C}$ at $8 \mathrm{~m}$ and 7.0 to $7.1^{\circ} \mathrm{C}$ at $10 \mathrm{~m}$. The effect of irradiance was assessed by using clear bags, bags that were a neutral density grey, and bags with shade cloth tied around them. This replicated light levels at 6 to $11 \mathrm{~m}$ in Ace Lake. Measurements indicated that maximum PAR across these depth ranged on average from 20 to $2 \mu \mathrm{mol} \mathrm{m}^{-2} \mathrm{~s}^{-1}$ at solar noon each day. Salinity was assessed by the addition of $\mathrm{NaCl}$ to raise the salinity from 18.1 to $29.9 \mathrm{~g} \mathrm{~kg}^{-1}$. The effects of nutrients were assessed by the addition of $5 \mathrm{ml}$ of SNAX medium to some bags. Subsamples were collected every $12 \mathrm{~h}$ over $48 \mathrm{~h}$ from each treatment under low light conditions to prevent photoinhibition. PAR, salinity and temperature were monitored throughout the experiments in Ace Lake down to a $13 \mathrm{~m}$ depth as indicated above. The experiments were repeated 3 times over a period of $2 \mathrm{wk}$, during which time ice conditions of the lake did not change nor was there any snow precipitation. Because of logistical constraints, samples needed to be stored before flow cytometry analysis.
Experimentation revealed that nearly $100 \%$ of Synechococcus cells fixed in $1 \%$ (vol./vol.) glutaraldehyde $(\mathrm{pH} 7.0)$ at $5^{\circ} \mathrm{C}$ for $30 \mathrm{~min}$ and then frozen and stored in liquid $\mathrm{N}_{2}$ were recoverable for flow cytometry as long as samples were rapidly thawed just before analysis (Lepesteur et al. 1993). Growth and grazing rates were determined using the equation: $r=k-g=\ln \left(N_{t} / N_{0}\right) / t$ where $N_{0}$ is the cell abundance at Time zero, $N_{t}$ is the cell abundance at Time $t, r$ is the net growth rate. Specific growth rate $(k)$ was measured from the rate of increased cell density in the cycloheximide treatments while grazing rate $(g)$ was calculated from the rate of cell density reduction in the ampicillin treatment minus the control. Analysis of variance (ANOVA) was used to determine significance and interactions between treatments using the SAS programme (SAS Institute).

\section{RESULTS}

\section{Characteristics of Ace Lake}

During the seasonal survey, the top $7 \mathrm{~m}$ of Ace Lake was mixed, with summer and winter temperatures of 2 to $5.5^{\circ} \mathrm{C}$ and $-1^{\circ} \mathrm{C}$, respectively, and salinity ranging between 13 to $16 \mathrm{~g} \mathrm{~kg}^{-1}$ depending on the ice-cover thickness. Between 7 and $15 \mathrm{~m}$, the oxygenated middle zone had a higher temperature, peaking at $10.5^{\circ} \mathrm{C}$ in February and dropping to $4.5^{\circ} \mathrm{C}$ in August to November (Fig. 1A). Salinity in this layer increases rapidly from 16 to $28 \mathrm{~g} \mathrm{~kg}^{-1}$ with depth in the pycnocline from 7 to $9 \mathrm{~m}$. The $\mathrm{pH}$ in the lake was relatively constant, ranging from 8.1 to 8.5 , with values slightly higher in summer than in winter. Light measurements indicated that PAR reached a maximum of $35 \mu \mathrm{mol}$ photons $\mathrm{m}^{-2}$ $\mathrm{s}^{-1}$ at $10 \mathrm{~m}$ during January, while at the same depth PAR was below the detection limit between April and October. The depth of the euphotic zone was $<3 \mathrm{~m}$ during winter, but increased to $10-11 \mathrm{~m}$ over summer (Fig. 1B). DOC concentrations in the aerobic zone of Ace Lake were always less than $10 \mathrm{mg} \mathrm{l}^{-1}$, with levels highest at the $10 \mathrm{~m}$ depth over winter ( 8 to $9 \mathrm{mg} \mathrm{l}^{-1}$ ) and lowest at the end of summer $\left(6 \mathrm{mg} \mathrm{l}^{-1}\right)$ (Fig. 1A). Nitrate was below detection limits in the aerobic zone of Ace Lake in late November. Phosphate concentration increased with increasing depth (see Fig. 4).

\section{Microbial populations in Ace Lake}

Flow cytometry analysis revealed that Synechococcus populations were below $10^{5}$ cells $\mathrm{ml}^{-1}$ (Fig. 1C). During summer, numbers increased by 2 orders of magnitude up to the highest reading of $8 \times 10^{6} \mathrm{cells} \mathrm{ml}^{-1}$ at a 

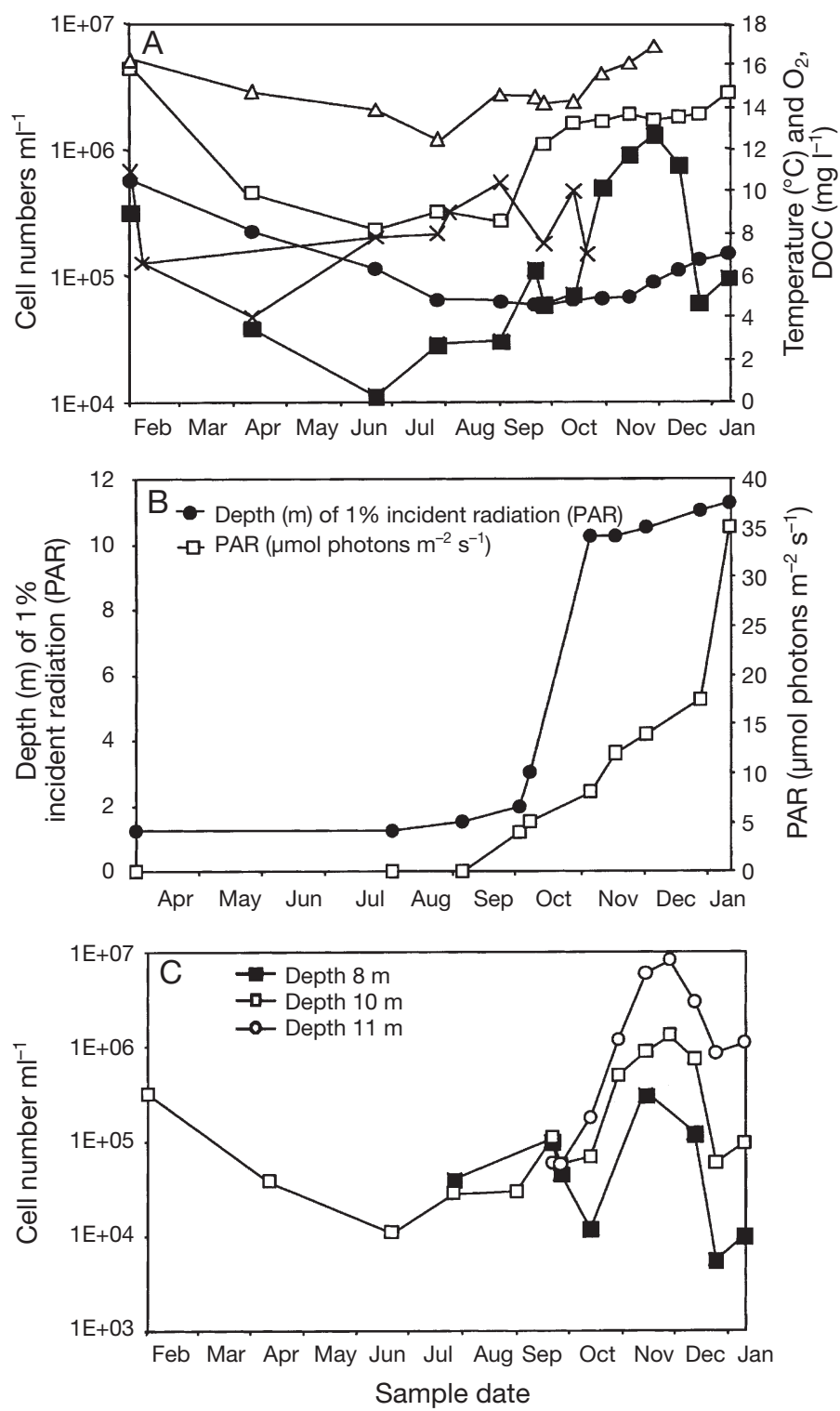

Fig. 1. Synechococcus. Seasonal survey of cells in Ace Lake. (A) Synechococcus cell (অ) and bacterial () populations in relation to temperature $(\bullet), \mathrm{O}_{2}(\Delta)$ and DOC $(\mathbf{X})$ at $10 \mathrm{~m}$ depth; (B) irradiance profile; (C) Synechococcus cell populations at 8,10 and $11 \mathrm{~m}$ depth

depth of $11 \mathrm{~m}$ in December (Fig. 1C). The number of Synechococcus cells was consistently greater at a depth of $11 \mathrm{~m}$ than at 8 and $10 \mathrm{~m}$ (Fig. 1C). Heterotrophic bacterial numbers on the other hand increased in summer by only about 4 -fold at a depth of $10 \mathrm{~m}$ (Fig. 1A). The initiation of the picocyanobacterial bloom occurred in October, when PAR at 10 to $11 \mathrm{~m}$ increased to above $5 \mu \mathrm{mol}$ photons $\mathrm{m}^{-2} \mathrm{~s}^{-1}$. By the time PAR had reached the maximum level in January, the picocyanobacterial bloom was in decline (Fig. 1B,C). The increase in numbers of picocyanobacteria also corresponded with supersaturation of dissolved oxygen below the pycnocline, with concentrations rising from $13 \mathrm{mg} \mathrm{l}^{-1}$ in winter to about $17 \mathrm{mg} \mathrm{l}^{-1}$ in summer (Fig. 1A).

\section{Distribution in relation to eukaryotic phytoplankton}

The contribution of picocyanobacteria to the primary production rates in Ace Lake was not directly measured; however, based on total phytoplankton cell surface area, picocyanobacteria dominated in Ace Lake below the pycnocline during late November when the bloom peaked (Fig. 2). Using flow cytometry and microscopy, 4 major eukaryotic phytoplankters were identified in Ace Lake in addition to Synechococcus: Mesodinium rubrum, Pyramimonas gelidicola, a Cryptomonas sp. and a phototropic nanoplankter; these algae dominated the upper layers of Ace Lake to varying degrees (Fig. 2). Flow cytometry indicated that the nanoplankter was 2 to $3 \mu \mathrm{m}$ in diameter and produced a strong chlorophyll a fluorescent signal.

\section{Photoadaptation and diel periodicity}

Over the summer period (October to December), flow cytometry revealed that red (mostly chlorophyll a) and orange fluorescence (phycoerythrin) of individual picocyanobacterial cells declined with increased PAR at $10 \mathrm{~m}$. The ratio of phycoerythrin to chlorophyll a decreased from 1.3 in October to 0.7 in December. The cyanobacterial population in Ace Lake was closely monitored in December to determine if diel periodicity in irradiance occurred. PAR over $12 \mathrm{~h}$ cycles at the 8 to $11 \mathrm{~m}$ depth varied from 0 to 2.5-4.5 $\mu \mathrm{mol}$ photons $\mathrm{m}^{-2} \mathrm{~s}^{-1}$ during the period, and only slight variations in cell distribution was observed

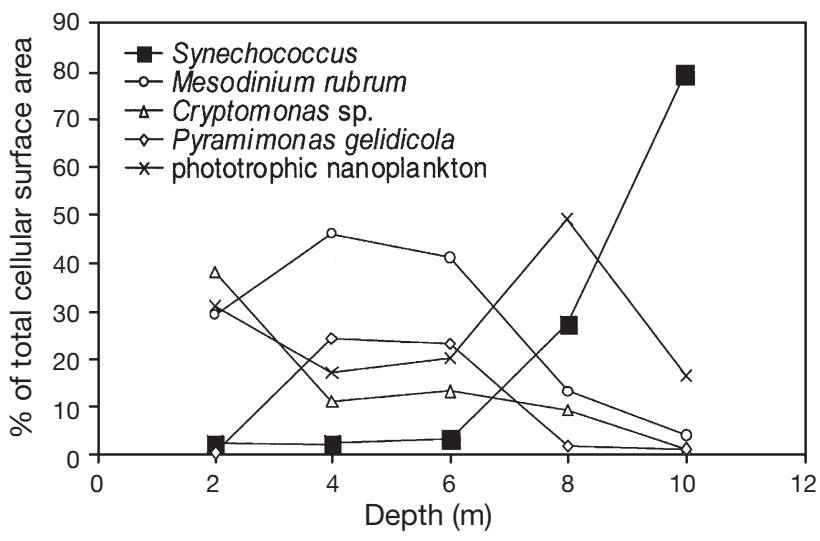

Fig. 2. Synechococcus. Contribution of cells to phytoplankton (shown as total cell surface areas in Ace Lake) 
over a series of $24 \mathrm{~h}$ experiments (data not shown). Diel periodicity, a common phenomenon in natural populations of Synechococcus spp. (Prézelin 1992), may not have been detected here due to low growth rates of the picocyanobacteria in Ace Lake (Fahnenstiel et al. 1991).

\section{Controls on in situ growth rates of Ace Lake picocyanobacteria}

The results from the metabolic inhibitor study did not indicate any significant correlation ( $p>0.128)$ between picocyanobacterial growth rates and grazing pressure. In addition, different antibiotic treatments, which incorporated the effects of light levels as a further variable effect, showed no differences. No significant effects resulted from moderate variations in salinity $(F=0.06, \mathrm{p}=0.80)$ or nutrients $(F=0.19, \mathrm{p}=0.66)$. The only first-order interaction (ANOVA analysis) that corresponded to a significant change in growth rate was temperature, which was related directly to water depth and light $(\mathrm{p}<0.035)$, with increased temperature and lower light resulting in greatest increases in growth rate (Fig. 3A). The reduction of light using shading also caused increases in growth rates, although this was only significant in samples suspended at $10 \mathrm{~m}$ $(p=0.008)$ (PAR 8: Fig. 3B).

\section{Picocyanobacteria in other Vestfold Hills lakes and coastal areas}

Several Vestfold Hills lakes and coastal waters (Table 1) were surveyed during November for picocyanobacteria. Besides Ace Lake (Fig. 4), populations were only de-
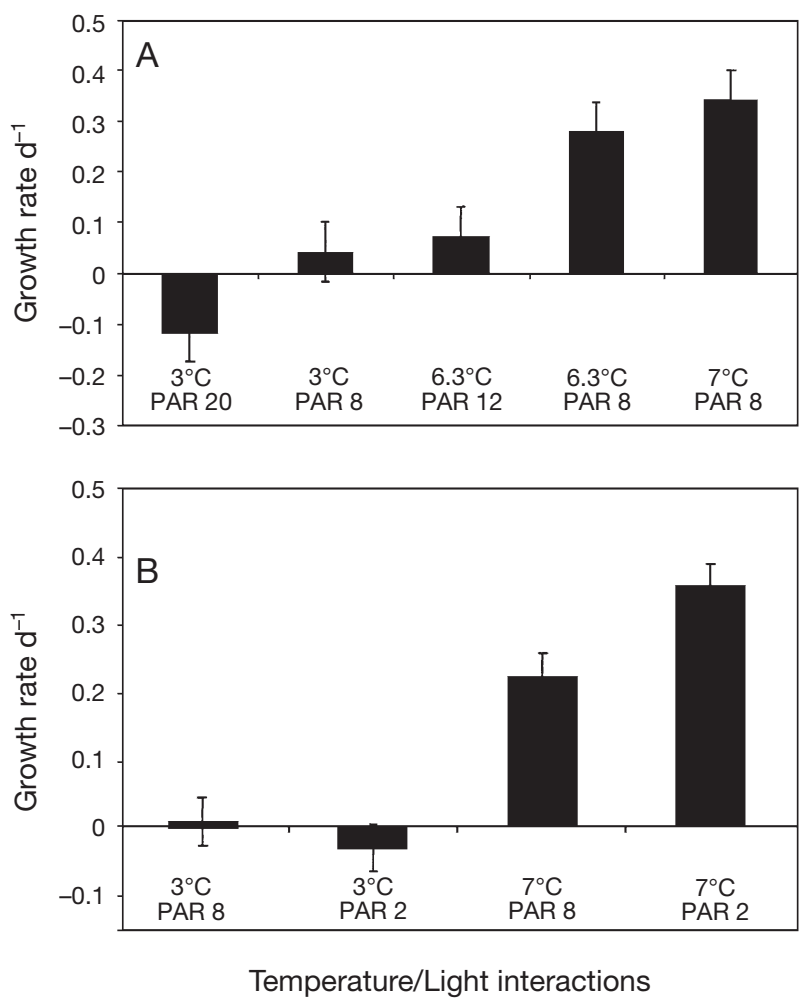

Fig. 3. Synechococcus. In situ growth of cells in Ace Lake showing interactions of temperature and light. Temperature and photosynthetically available radiance (PAR) ( $\mu \mathrm{mol}$ photons $\mathrm{m}^{-2} \mathrm{~s}^{-1}$ ) to which sample bags were exposed are indicated. Temperature remained nearly constant during course of experiment; PAR levels indicated were maximum levels reached at noon. (A) Mean $(+\mathrm{SE})$ growth rates at 3 depths and light intensities. (B) Mean (+SE) growth rates in sample bags suspended and incubated at 2 depths, with some bags shaded from light such that maximum PAR was reduced to approximately $2 \mu \mathrm{mol}$ photons $\mathrm{m}^{-2} \mathrm{~s}^{-1}$ (see 'Materials and methods' for further details)

Table 1. Synechococcus and bacterial populations in different Vestfold Hills lakes and coastal areas sampled in mid-summer. The level of PAR was measured at noon at the time of sampling and is shown in relation to the depth range sampled. bld: below limits of detection; nd: no cells detected; na: not available

\begin{tabular}{|c|c|c|c|c|c|c|c|c|c|}
\hline Water body & $\begin{array}{l}\text { Depth range } \\
\text { sampled (m) }\end{array}$ & $\begin{array}{l}\text { Synechococcus } \\
\left(\times 10^{4} \text { cells ml }^{-1}\right)\end{array}$ & $\%$ of PAR & $\begin{array}{c}\text { Bacteria } \\
\left(\times 10^{4} \text { cells } \mathrm{ml}^{-1}\right)\end{array}$ & $\begin{array}{c}T \\
\left({ }^{\circ} \mathrm{C}\right)\end{array}$ & $\begin{array}{l}\text { Salinity } \\
\left(\mathrm{g} \mathrm{kg}^{-1}\right)\end{array}$ & $\begin{array}{c}\text { Phosphate } \\
(\mu \mathrm{M})\end{array}$ & $\begin{array}{c}\text { Nitrate } \\
(\mu \mathrm{M})\end{array}$ & $\begin{array}{c}\text { DOC } \\
\left(\mu g l^{-1}\right)\end{array}$ \\
\hline Ace Lake & $4-11$ & $0.13-80.7$ & $6.4-2.4$ & $63.1-532$ & $1.4-6.6$ & $18.1-29.9$ & $0.26-8.8$ & bld & $5.4-7.7$ \\
\hline Lake Abraxas & $3-19$ & $0.005-1480$ & $7.2-1.0$ & $10.3-24$ & $0.5-8.0$ & $16.8-20.3$ & $0.06-0.2$ & bld -0.21 & $3.1-4.0$ \\
\hline Pendant Lake & $5-13$ & $871-1500$ & $1.1-0.7$ & $480-667$ & $0.2-0.8$ & $16.5-31.0$ & $0.8-1.3$ & bld & $4.0-5.3$ \\
\hline Taynaya Bay & $3-16$ & nd & $3.1-1.0$ & $50.3-80.6$ & $-1.9--1.6$ & $35.2-44.2$ & $0.9-14.4$ & $5.1-21.9$ & $1.8-2.4$ \\
\hline Coastal marine & 5 & nd & 0.09 & 8.6 & -1.9 & 34.6 & 2.0 & 14.9 & 1.7 \\
\hline Burton Lake & $4-12$ & nd & $0.01-0.04$ & $115-158$ & -2.3 & $43.3-43.5$ & $10.5-27.4$ & $0.6-1.1$ & $2.4-2.6$ \\
\hline Lake McCallum & $5-20$ & nd & $3.6-0.1$ & $4.2-8.6$ & $1.4-6.6$ & $14.8-18.2$ & $0.09-0.13$ & bld & $6.5-7.4$ \\
\hline Clear Lake & $5-30$ & nd & $17.0-0.35$ & $9.4-11.7$ & $1.4-7.0$ & $10.3-12.7$ & na & na & nd \\
\hline Ekho Lake & $4-20$ & nd & $44-1.7$ & $7.1-585$ & $8.2-17.6$ & $59.8-124.6$ & na & na & na \\
\hline Organic Lake & $2-6$ & nd & $2.3-0.02$ & $530-1360$ & $-10.7--7.8$ & 179.6-206.1 & na & na & na \\
\hline Fletcher Lake & $2-6.5$ & nd & 6-1.4 & $19.7-233$ & $-2.5-2.8$ & $56.4-81.8$ & na & na & na \\
\hline
\end{tabular}


tected in Lake Abraxas and Pendant Lake on the basis of flow cytometry (Table 1). In Lake Abraxas Synechococcus populations were stratified, with greatest cell numbers at depths of 19 to $20 \mathrm{~m}$, corresponding to a temperature of 7 to $8^{\circ} \mathrm{C}$ (Fig. 4). PAR at this depth was about $1 \%$ of the total incident light recorded at the time (Fig. 4). In comparison, Synechococcus cells were much less stratified in Pendant Lake, which had a more even temperature distribution $\left(0.1\right.$ to $\left.1.1^{\circ} \mathrm{C}\right)$ (Fig. 4). Only slightly greater populations occurred below the pycnocline at $11 \mathrm{~m}$. PAR throughout much of Pendant Lake was between 0.7 and $1.1 \%$ of the total incident light (Fig. 4).

\section{Isolation and morphological data}

Non-axenic cultures (designated strains Abraxas, Ace and Pendant) were successfully obtained from 3 Antarctic lakes in the SNAX medium. Growth also occurred to a lesser extent in $f / 2$ and FE media, with the Synechococcus representing a minority component of enrichments, dominated by diatoms. No growth occurred in SOX medium (Waterbury 1992), suggesting that the lake Synechococcus were unable to fix nitrogen. No growth was found in media prepared with coastal seawater. After the primary inoculation,
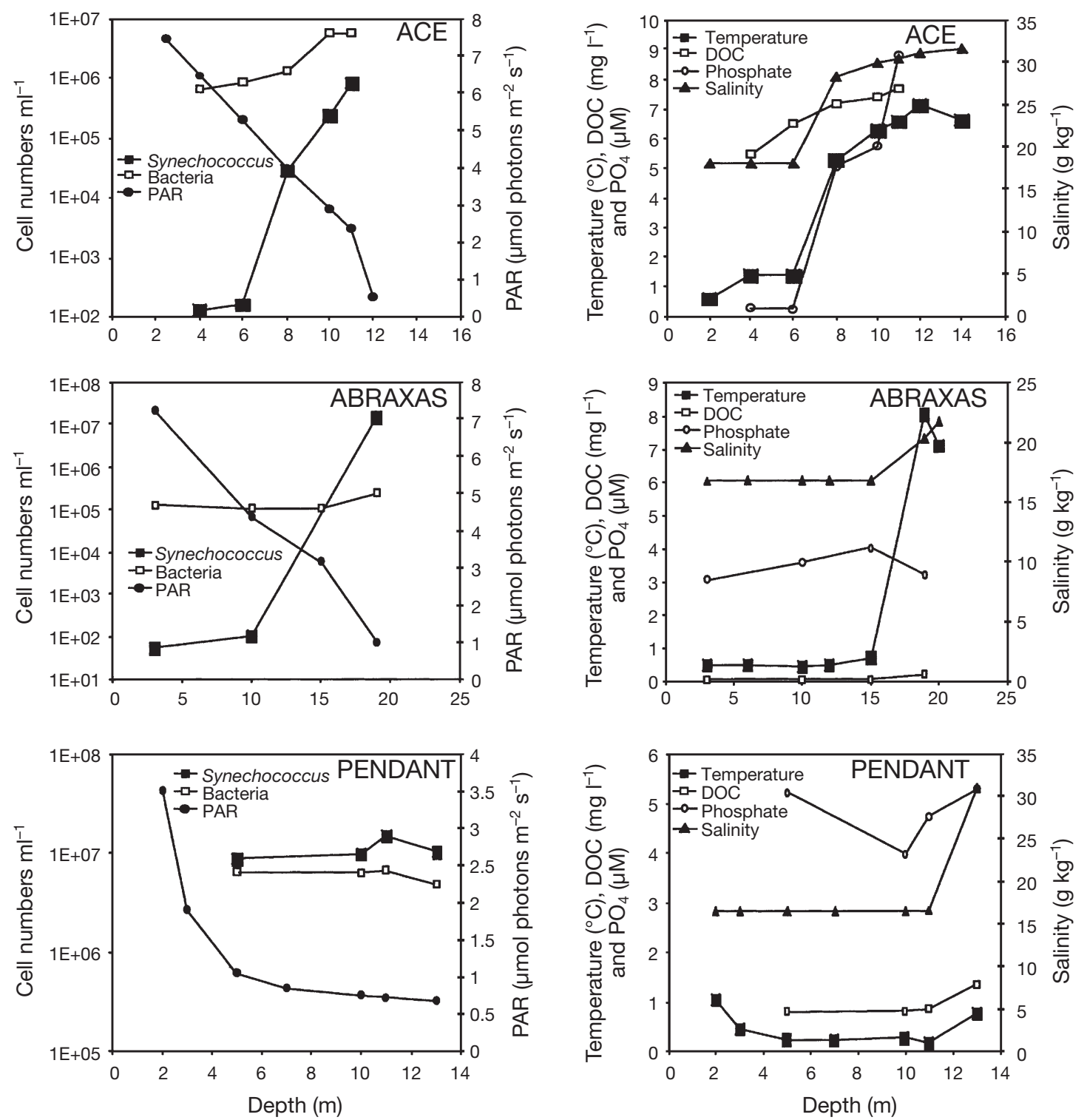

Fig. 4. Synechococcus. Cell population distribution in aerobic zones of Vestfold Hills saline lakes in late November, showing maximal numbers below pycnocline. Graphs on left compare Synechococcus cells and bacterial populations with PAR levels; graphs on right show the relations of temperature, salinity, DOC and soluble reactive phosphate over depth 


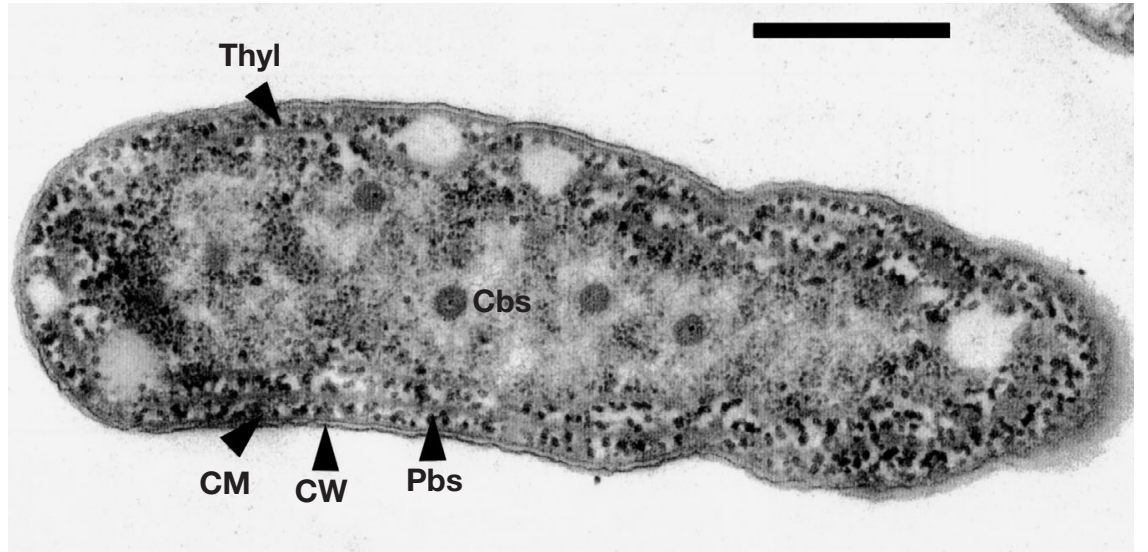

Fig. 5. Synechococcus. Electron micrograph of Ace Lake strain. Cells were grown under $30 \mu \mathrm{mol}$ photons $\mathrm{m}^{-2} \mathrm{~s}^{-1}$ at $10^{\circ} \mathrm{C}$. Cellular features indicated by arrowheads. CW: cell wall; CM: cell membrane; Thyl: thylakoid membrane; Pbs: phycobilisomes; Cbs: carboxysomes. Scale bar $=540 \mathrm{~nm}$
455/485 nm, respectively. When grown under high light conditions $\left(100 \mu \mathrm{mol}\right.$ photons $\mathrm{m}^{-2}$ $\mathrm{s}^{-1}$ ) the ratios of lipid-soluble pigments shifted, with a 7-fold decline in chlorophyll a, a 3-fold decline in $\beta, \beta$-carotene, and 2 to 3 -fold increases in the proportions of the zeaxanthin-type carotenoids (Fig. 6B). The fatty acids of Strain Ace consisted mainly of $16: 1 \omega 7 \mathrm{C}$ (43 to $50 \%$ ), 14:0 (18 to $28 \%), 16: 0$ (10 to $12 \%), 18: 1 \omega 7 \mathrm{C}$ ( 1 to $3 \%$ ) and $18: 0$ ( 2 to $6 \%$ ), with profiles of cells grown at early and late logarithmic growth phase only varying slightly. growth did not occur on SNAX media solidified with agar or agarose. Antibiotic selection reduced heterotrophic bacterial contaminants to a level of $<1 \%$ of the total cell population in SNAX media, and only 1 homogenous strain was observed by microscopy (confirmed subsequently by $16 \mathrm{~S}$ rRNA gene sequence analysis). Under epifluorescent microscopy, all 3 strains fluoresced orange-red under green light and were fairly uniform in size ( 0.9 to $1.1 \mu \mathrm{m} \times 1.5$ to $1.8 \mu \mathrm{m})$ and appeared as coccibacilli or short rods. Transmission electron microscopy revealed that the cells contained thylakoid membranes, phycobilisomes (20.3 \pm 5.7 diameter) and carboxysomes (85 nm diameter) (Fig. 5). The cultures were confirmed as representatives of the dominant population in Ace Lake, Lake Abraxas and Pendant Lake on the basis of lipid-soluble pigment profiles from the cultures and lake water particulates, which have the same relative proportions of photosynthetic and carotenoid pigments (Fig. 6A). Pigments in extracts from Lake Abraxas and Pendant Lake were very similar to those of Ace Lake. Water bodies that did not contain Synechococcus cells (as determined by flow cytometry) had different pigment profiles.

\section{Chemical aspects of Synechococcus isolates}

In vivo spectra were similar for all strains, with wavelength peaks indicating that the cells contained mostly chlorophyll $a$, phycoerythrin and lesser amounts of phycocyanin and allophycocyanin. An absorbance peak at $495 \mathrm{~nm}$ indicated the presence of $\beta, \beta$-carotene. HPLC analysis of the Ace strain (Fig. 6B,C), confirmed the presence of chlorophyll $a, \beta, \beta$-carotene, zeaxanthin and 2 other unknown zeaxanthin-like carotenoids, which had absorption spectra at 454/484 nm and

\section{Physiology of Synechococcus isolates}

Strain Ace exhibited fastest specific growth $\left(0.13 \mathrm{~d}^{-1}\right)$ at about $20^{\circ} \mathrm{C}$. At 1.7 and $27.4^{\circ} \mathrm{C}$, growth rates were only about $0.04 \mathrm{~d}^{-1}$. The Ratkowsky growth kinetic model, fitted the data well, with an RMSE deviation of only $5.3 \%$ (Fig. 7). The minimum growth temperature $\left(T_{\min }\right)$ was $-17.0 \pm 8.7^{\circ} \mathrm{C}$, optimum temperature $\left(T_{\text {opt }}\right)$ was $19.7^{\circ} \mathrm{C}$ and maximum temperature $\left(T_{\max }\right)$ was $29.5 \pm 1.3^{\circ} \mathrm{C}$. Cells exposed to low light levels $(5 \mu \mathrm{mol}$ photons $\mathrm{m}^{-2} \mathrm{~s}^{-1}$ ) decreased in cell yield relative to controls $(\mathrm{p}<0.0001)$ and resulted in 4 - to 5 -fold increases in orange and red fluorescence intensities. High light conditions (300 $\mu \mathrm{mol}$ photons $\mathrm{m}^{-2} \mathrm{~s}^{-1}$ ) did not affect growth yield substantially. Orange and red cell fluorescence was reduced by 90 and $45 \%$, respectively, in relation to the control culture grown at $20 \mu \mathrm{mol}$ photons $\mathrm{m}^{-2} \mathrm{~s}^{-1}$ on a $12 \mathrm{~h}$ light/dark cycle. For optimal growth, the Ace Lake strain required salinities of 20 to $30 \mathrm{~g} \mathrm{~kg}^{-1}$. No growth occurred at salinities of $<10 \mathrm{~g}$ $\mathrm{kg}^{-1}$ or $>50 \mathrm{~g} \mathrm{~kg}^{-1}$. No effect on cell volume was found when cells were grown at different salinities or light levels.

\section{Phylogenetic and genotypic characteristics}

All 3 lake strains were very closely related (16S rRNA gene sequence similarity $>98 \%$ ) and formed a distinct, peripheral lineage within the Prochlorococcus/ Synechococcus clade (Fig. 8). The closest available published sequences were from Synechococcus Strains WH5701 (Fuller et al. 2003), P211 (Vincent et al. 2000) and BO0014 (Ernst et al. 2003), which were 95 to $96 \%$ similar. Similarities to other sequences in the larger Synechococcus clade ranged from 93 to $95 \%$. 

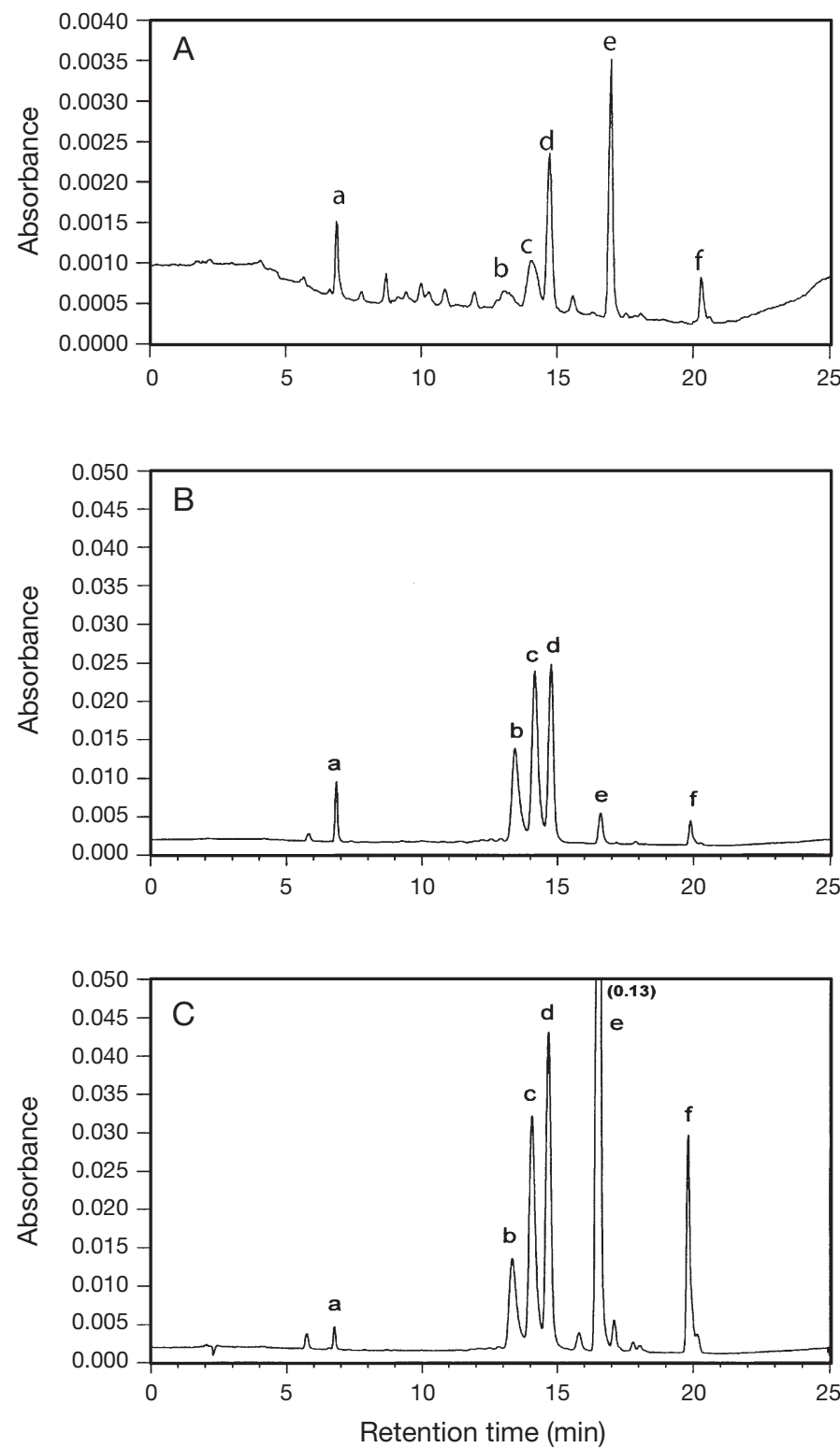

Fig. 6. Synechococcus. HPLC lipid-soluble pigment profile of (A) Ace Lake particulates from depth of $10 \mathrm{~m}$; (B) Ace Lake strain under strong light $\left(100 \mu \mathrm{mol}\right.$ photons $\left.\mathrm{m}^{-2} \mathrm{~s}^{-1}\right)$; (C) Ace Lake strain under low light $\left(5 \mu \mathrm{mol}\right.$ photons $\left.\mathrm{m}^{-2} \mathrm{~s}^{-1}\right)$. Peak identification $=\mathrm{a}$ : me-chlorophyllide; $\mathrm{b}$ : unknown carotenoid; c: unknown carotenoid; d: zeaxanthin; e: chlorophyll $a_{\text {; }}$ and f: $\beta, \beta$-carotene. Peaks identified by comparison with authentic standards and cultures

The Antarctic Lake strains had DNA base compositions of 56 to $57 \mathrm{~mol} \%$. The strains also represented a single genospecies as they shared high levels of DNA hybridisation. The Ace Lake and Pendant Lake strains hybridised at $88 \pm 10 \%$, the Ace Lake and the Lake Abraxas strain hybridised at $77 \pm 8 \%$, and the Pendant Lake and Lake Abraxas strains hybridised at a level of $74 \pm 5 \%$.

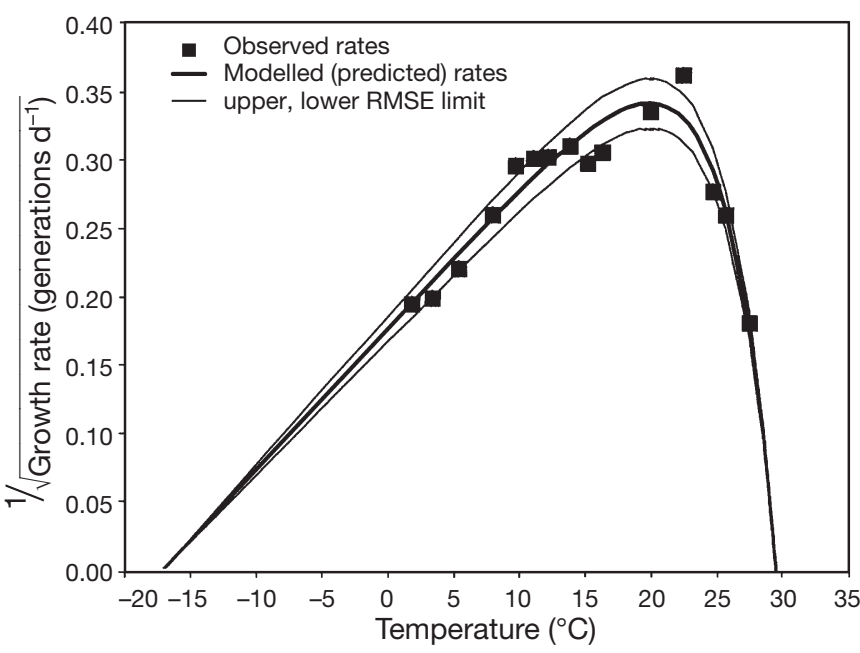

Fig. 7. Synechococcus. Theoretical growth curve, obtained from 4 parameter, square-root growth kinetic model of Ratkowsky et al. (1983), showing actual data points obtained during temperature gradient experiments. Irradiance was $20 \mu \mathrm{mol}$ photons $\mathrm{m}^{-2} \mathrm{~s}^{-1}$. Upper and lower root mean-square error (RMSE) limits for model based on the fitted data are shown

\section{DISCUSSION}

\section{Population dynamics}

Although meromictic Ace Lake has been much studied, reports of picocyanobacteria in this lake and the other maritime lakes of Vestfold Hills have been sparse and of a preliminary nature (Rankin et al. 1997, Vincent et al. 2000). Using flow cytometry, distinct phycoerythrin-containing picocyanobacterial blooms could be readily visualized as distinctly stratified populations (Fig. 1C) in certain saline, meromictic Vestfold Hills lakes (Table 1, Fig. 4). Stratified distributions of phycoerythrin-rich picoplankton have also been observed in various tropical and temperate meromictic lakes (Maeda et al. 1992, Venkateswaran et al. 1993), and are maintained by active cell division overcoming net losses from grazing and sinking. The picocyanobacteria here were identified as members of form genus Synechococcus (Herdman et al. 2001) on the basis of pigment content, cell morphology and binary cell division, which occurred only across a single plane. Blooms of Synechococcus in Ace Lake, occurred within the stable zone below the pycnocline (Fig. 1B,C) and corresponded in response to increases in PAR (Fig. 1A) and water temperature (Fig. 1B) during spring, a phenomenon that has also been observed in freshwater polar and subpolar lakes (Vezina \& Vincent 1997). Populations of marine picocyanobacteria typically reach maxima of $10^{2}$ to $10^{4}$ cells $\mathrm{ml}^{-1}$ in open ocean regions and $10^{4}$ to $10^{6}$ cells $\mathrm{ml}^{-1}$ in temperate and trop- 
Fig. 8. 16S rRNA gene-based phylogram comparing various Synechococcus spp. and related strains. Antarctic lake strain sequences compared were 1389 nucleotides in length, and distances were generated using maximum-likelihood algorithm and clustered using neighbour-joining method. Clusters are designations for potential new genera making up form genus Synechococcus (Herdman et al. 2001). GenBank accession numbers are given after each strain. Bootstrap values (>70\%) are shown at branch nodes and were calculated from 500 replicates. Distance bar $=0.1$ nucleotide substitutions per sequence position

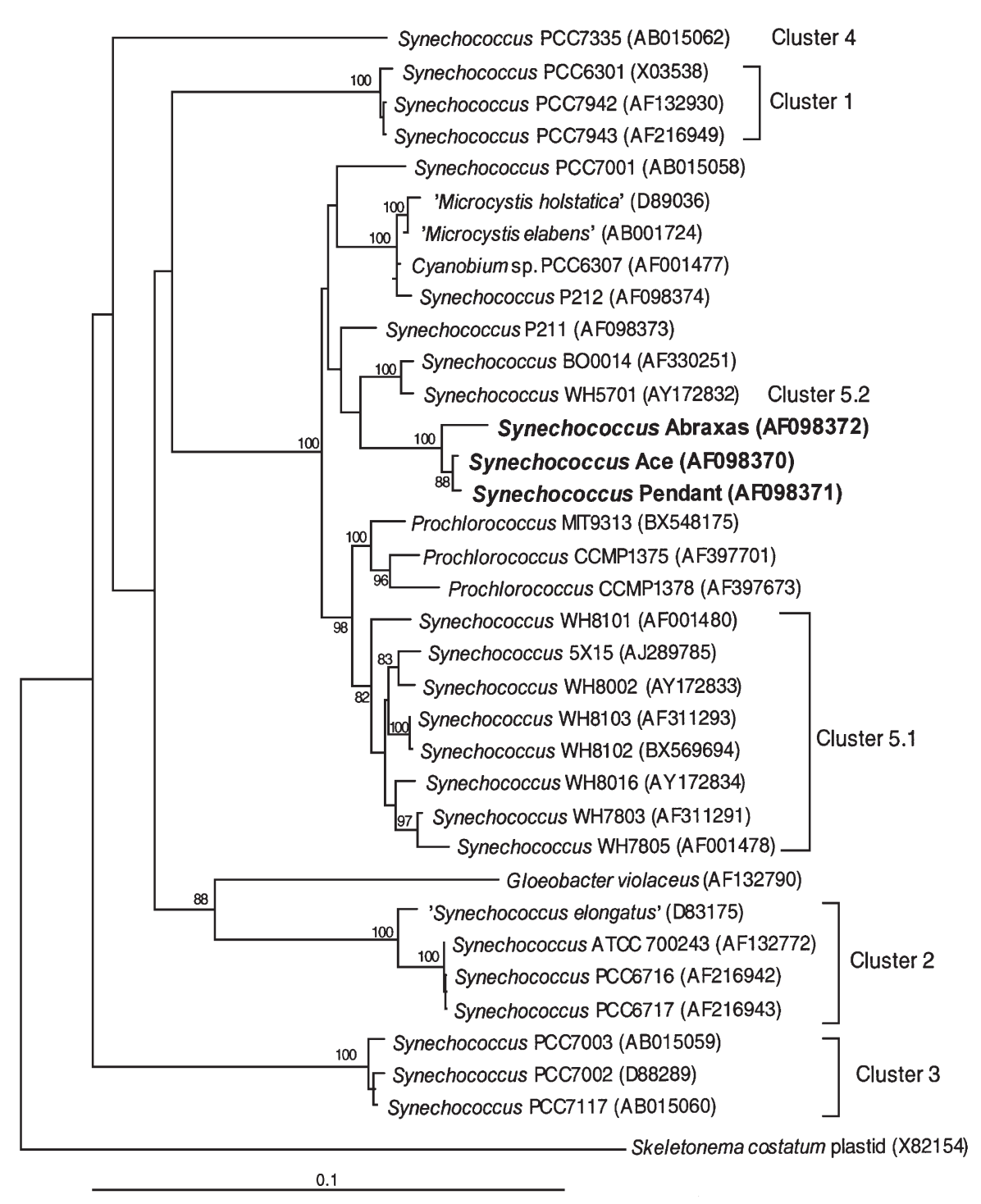

ical coastal waters and lakes (e.g. Maeda et al. 1992, Phlips et al. 1999), with greater populations in summer than in winter. Southern Ocean, Antarctic coastal and oligotrophic lake waters contain very low picocyanobacterial populations (Marchant et al. 1987, Letelier \& Karl 1989, Walker \& Marchant 1989, LaybournParry \& Marchant 1992), possibly due to temperature and nutrient limitations. By comparison, eutrophic lakes on Signy Island, Antarctica, host greater populations of picocyanobacteria $\left(10^{4}\right.$ to $10^{8}$ cells ml $^{-1}$; Hawes 1990). In the present study, picocyanobacterial blooms of $10^{5}$ to $10^{7}$ cells ml ${ }^{-1}$ were observed in non-eutrophic, meromictic Vestfold Hills lakes (Table 1).

Experiments were performed to observe the interactions of light, salinity, nutrients and temperature (which effectively incorporated grazing loss) on Synechococcus cells in Ace Lake. Populations exhibited very low growth or net losses at $6 \mathrm{~m}$ depth whether the light intensity was low or high (Fig. 3). Since culture studies indicate that growth at $3^{\circ} \mathrm{C}$ is about $0.06 \mathrm{~d}^{-1}$, grazing could account for low levels of biomass production. A combination of decreased light and increased temperature, which occurred at a depth of $10 \mathrm{~m}$ in Ace Lake, resulted in increased growth rates. The increase in growth rate compensated for grazing losses and resulted in net biomass production and the highest net population growth rates (Fig. 3). Preliminary data from the seasonal survey of the Synechococcus cell populations showed that the mixed-zone populations increased by only about 10-fold from September to October. This small population increase may have been affected by grazing; however, the effect of temperature may have been a critical factor resulting in a smaller net gain over the spring bloom period. At 10 to $11 \mathrm{~m}$, at which the greatest cell numbers occurred, the specific growth rate during the bloom 
period was estimated at $0.07 \mathrm{~d}^{-1}$. This growth rate was quite similar to the growth rate in laboratory cultures of the Antarctic lake strains at 7 to $8^{\circ} \mathrm{C}$, and similar to the growth rates of Synechococcus spp. in polar oceans (Neuer 1992). In comparison, growth rates for Synechococcus spp. in temperate and tropical locations can be $>1 \mathrm{~d}^{-1}$ (Waterbury 1992). Growth rates estimated during the in situ lake experiments often exceeded those determined from laboratory culture studies conducted at the same temperature (e.g. at $7^{\circ} \mathrm{C}$ in Ace Lake at $10 \mathrm{~m}$ growth was up to $0.34 \mathrm{~d}^{-1}$, while the culture studies estimate only $0.07 \mathrm{~d}^{-1}$ for an equivalent temperature). This large difference could have been due to experimental artefacts introduced into either the field or laboratory experiments such as the effects of the containment of the populations in the sample bags, or self-shading.

\section{Effect of irradiance, nutrients and salinity}

Primary production in Ace Lake is relatively low compared to that in Antarctic coastal waters, being estimated at 0.5 to $0.7 \mu \mathrm{g} \mathrm{C} 1^{-1} \mathrm{~h}^{-1}$ (Laybourn-Parry \& Perriss 1995). Mesodinium rubrum is the most dominant phytoplankter in the Ace Lake mixed zone (Fig. 2). Synechococcus cells made the greatest contribution to Ace Lake primary production, below the pycnocline (Fig. 2). Synechococcus cells in the Vestfold Hills lakes appeared to prefer overall lower light intensities. In spring, Synechococcus cells growth was initiated at between 1 and $5 \mu \mathrm{mol}$ photons $\mathrm{m}^{-2} \mathrm{~s}^{-1}$, with greatest cell concentrations occurring in zones with light intensities of 5 to 20 photons $\mu \mathrm{mol}$ photons $\mathrm{m}^{-2}$ $\mathrm{s}^{-1}$, corresponding to about $1 \%$ of the incident light at the time. Culture studies indicated that growth yield was slightly lower under dim light $\left(5 \mu \mathrm{m}\right.$ photons $\mathrm{m}^{-2}$ $\mathrm{s}^{-1}$ ), but growth rates and cell volumes were unaffected. Flow cytometry of Ace Lake samples also showed that the Synechococcus cells were photoadapting over summer, since from the onset of the spring bloom, phycoerythrin levels declined with increasing in PAR. Although light itself alone was not a significant factor affecting growth $(p>0.35)$ in the in situ experiments, when combined with temperature it was ( $p=0.008)$. Overall, the light intensities encountered by the Synechococcus cells at $11 \mathrm{~m}$ in Ace Lake were essentially optimal for cell yield; in comparison, the effect on growth rates were not as significant. The enhancement in the levels of 2 structurally unidentified zeaxanthin-like carotenoids in the Synechococcus cell cultures may be linked to protection against photooxidative stress (Baroli et al. 2003), since the proportionate levels of these carotenoids were markedly elevated at $100 \mu \mathrm{m}$ photons $\mathrm{m}^{-2} \mathrm{~s}^{-1}$ (Fig. 6B).
Within Ace Lake, the Synechococcus cell bloom was associated with oxygen supersaturation, probably due to active oxygenic photosynthesis. Synechococcus spp. can potentially exhibit light-dependent sensitivity to oxygen, preferring lower oxygen when PAR is high (Glover \& Morris 1981). In this study, the Synechococcus cell numbers were low in those parts of the lake subjected to high irradiance levels, and populations were already in decline at the time of the annual light maximum in January. The growth of populations did not seem to be affected by the high oxygen level, perhaps because the PAR was relatively low and any oxidative damage to the photosynthetic apparatus was efficiently repaired (He \& Hader 2002). The high dissolved inorganic carbon concentrations in Ace Lake (Gibson 1999), which include bicarbonate ion concentrations higher than those found in seawater (typically $2.4 \mathrm{mM}_{\mathrm{i}}$ ZoBell 1946), suggest that photosynthesis would not be limited on the basis of $\mathrm{CO}_{2}$ availability. Ammonia, derived from the deeper anoxic zone, has also been found to be elevated in the middle layer of Ace Lake (5 to $25 \mu \mathrm{M}_{i}$ H. R. Burton pers. comm.), while SRP was quite high below the pycnocline. $\mathrm{N}$ and $\mathrm{P}$ thus seem to be more than sufficient to support higher Synechococcus cell populations in Ace Lake. This was suggested by the in situ experiment, which indicated that nutrient addition did not significantly stimulate growth. It is possible that a lack of response could have been due to slow acclimation to the extra nutrients provided. Alternatively, the relatively slow growth rate of the Synechococcus cells also suggests that nutrient depletion over the $48 \mathrm{~h}$ period of the experiment would not be significant.

A survey of various Vestfold Hills water bodies and coastal areas emphasized the preference of the Antarctic lake strains for a relatively narrow salinity range, corresponding to levels approaching that of seawater (Table 1). The absolute requirement for seawater is a property of form genus Synechococcus Clusters 4 and 5.1. Clusters 1 and 2 require freshwater and have low salt tolerance, while Cluster 3 is halotolerant but does not require $\mathrm{Na}^{+}$ions for growth. Seawater requirement, however, varies between strains of Cluster 5.2 (Herdman et al. 2001); for example, Strains BO0014 and P211, phylogenetic neighbours of the Antarctic strains were isolated from freshwater habitats. This suggests that salt requirement is a phylogenetically shallow trait amongst strains related to Clusters 5.1 and 5.2, and that salinity requirements are species-specific.

The incidence of Synechococcus cell populations was also dependent on PAR, with populations exhibiting highest cell yields under the same light regimes (Fig. 4) as those observed in Ace Lake (Fig. 1B). Like Ace Lake, Synechococcus cell populations were strati- 
fied in Lake Abraxas below a pycnocline and could access nutrients diffusing up from an anoxic lower zone. In comparison, Pendant Lake exhibited high populations of Synechococcus throughout much of its water column, possibly because of the deep mixing in this lake, with populations slightly higher below the pycnocline at 11 to $12 \mathrm{~m}$.

\section{Community interactions}

The Synechococcus cell bloom may have had the consequence of increasing bacterial heterotrophic populations in Ace Lake at $10 \mathrm{~m}$ (Fig. 1A), possibly driven by availability of DOC from photosynthate, lysing cells and from the 'sloppy' feeding of grazers. The subsequent growth of heterotrophs also reduced DOC levels by about $25 \%$ by the end of the summer season. An antibiotic selection method used in this study has been employed to determine grazing rates on Synechococcus cells in non-polar regions (Xiuren \& Vaulot 1992). However, data obtained here showed no significant effects between treatments. This suggests that grazing potentially had a negligible effect on population growth rates, although in the in situ growth experiments performed at $6 \mathrm{~m}$, net biomass losses were observed. The antibiotic method used, however, makes several major assumptions: firstly that organisms in situ grow exponentially; secondly, that they are not lysed significantly by the antibiotics; and finally that the antibiotics selectively inhibit the predator but not prey populations. Antibiotic concentrations used in the study had been pre-tested thoroughly in the laboratory on the Ace Lake strain and a cultured Cryptomonas sp. common in Ace Lake. It is quite possible that under field conditions, manipulations used and logistical constraints (samples had to be fixed and cryopreserved before analysis) led to population changes which obscured grazing effects. Synechococcus cell grazing rates have been estimated at 0.23 to $0.44 \mathrm{~d}^{-1}$ in various temperate and tropical coastal and oceanic areas (Xiuren \& Vaulot 1992, Liu et al. 1995), and often equal or exceed the specific growth rate. It is possible that the low growth rates in Ace Lake also added to the difficulty in estimating grazing rates. Ace Lake grazer populations have not been studied in great detail, but are known to include the ciliate mixotroph Mesodinium rubrum, copepods such as Paralabidocera antarctica, and heterotrophic microflagellates (LaybournParry \& Perriss 1995, Swadling \& Gibson 2000). Peak grazer populations usually occurred at $11 \mathrm{~m}$, where the maximum Synechococcus cell density is found. This could mean that total Synechococcus cell growth rates could be substantially greater than was measured directly in natural populations and equate better with the in situ growth experiments (e.g. $0.07 \mathrm{~d}^{-1}$ compared to $0.34 \mathrm{~d}^{-1}$ ). If this were the case, there is a contradiction between these results and the culture growth rate measurements, which indicated maximal growth rates at only $0.13 \mathrm{~d}^{-1}$ at a $T_{\text {opt }}$ of $19.7^{\circ} \mathrm{C}$. Nevertheless, the high populations achieved by the Synechococcus cells indicate that they are an integral part of the microbial loop in Ace Lake.

\section{Systematic biology of Synechococcus from Vestfold Hills lakes}

Phylogenetically, the Antarctic lakes strains were most closely related to strains of Cluster 5.2 (Marine Cluster B), including Synechococcus Strain WH5701 (Herdman et al. 2001) (Fig. 8). Although, morphologically they were indistinguishable and had similar fatty acid profiles (Merritt et al. 1991), other data, including DNA-base composition, pigment profiles, growth rates and light preference indicated that the Lake strains were quite different (Herdman et al. 2001). Strain WH5701 (Fuller et al. 2003) is the reference culture for Synechococcus Group 5.2 (Herdman et al. 2001), and is a halotolerant, C-phycoerythrin-lacking strain originally isolated from Long Island Sound, New York. Closely related strain Synechococcus sp. BO0014 (Ernst et al. 2003) is by comparison phycoerythrin-rich and isolated from freshwater (Lake Constance, Germany). Strain P211 is another freshwater strain isolated from a pond on Bylot Island in the Canadian high Arctic (Vincent et al. 2000). This strain lacks phycoerythrin, has a specific growth of $0.41 \mathrm{~d}^{-1}$, and prefers relatively high light intensities $(60 \mu \mathrm{mol}$ photons $\mathrm{m}^{-2} \mathrm{~s}^{-1}$ ). The Antarctic lake strains had a DNA-base composition substantially lower than the $66 \mathrm{~mol} \%$ value of Strain WH5701 (Herdman et al. 2001), further emphasizing the genetic difference between the strains.

Assuming that the nomenclature members of form genus Synechococcus will be revised, the lake strains would constitute at least a distinct species as they represent a distinct genospecies because of a DNA hybridisation level of $>70 \%$ (Wayne et al. 1987). This is also evident from the physiological, genotypic and phylogenetic distinctiveness of the Antarctic strains. Data for the Ace lake strain (Fig. 7) also indicated that the lake strains were cold-adapted, with cardinal temperatures well below those of temperate and tropical marine Synechococcus (Moore et al. 1995). The Antarctic lake strains were relatively slow-growing for Synechococcus spp., which typically grow at doubling times of 0.4 to $1.4 \mathrm{~d}^{-1}$. However, the rates are similar to those of Prochlorococcus spp. (Moore et al. 1995) and polar picocyanobacteria (Tang et al. 1997). The acqui- 
sition of psychrophily appears to result in physiological trade-offs, resulting in slower growth rates. This is possibly due to the energy requirements for maintenance of globular protein structural integrity (Ratkowsky et al. 2004). The Vestfold Hills saline lakes formed subsequent to deglaciation and marine uplift only about 8000 yr ago (Fulford-Smith \& Sikes 1996). It is thus possible that the Synechococcus strains studied here were trapped in the marine-derived ecosystems and subsequently thrived in locations that had environmental conditions favourable for their growth. Similar hypotheses have been posited for other bacteria isolated from saline Vestfold Hills lakes (Franzmann 1996).

\section{CONCLUSIONS}

It is possible that the Synechococcus sp. studied here is adapted to life at the bottom of the oceanic euphotic zone because of its preference for lower light conditions. However, low temperature would probably restrict it to negligible populations in Antarctic Zone waters (Marchant et al. 1987). Ace Lake, Pendant Lake and Lake Abraxas are all in close proximity to Long Fjord, and were isolated from the sea at about the same time only $8000 \mathrm{yr}$ ago. It would be of interest to sample the coastal and fjord zones at depth with various PCR-based molecular methods (DGGE, real-time PCR etc.) to determine if the picocyanobacteria there correspond to the lake strains. Utimately, Synechococcus populations in polar marine waters are highly dependent on a balance of rates of gain and loss (Vincent 2000). In the surface of Ace Lake, like that of the Southern Ocean, the rates of loss (grazing, turbulence of water) are high and the rates of gain (temperature) are low, resulting in low populations. Below the pycnocline of Ace Lake and Lake Abraxas, the loss rates are markedly offset by the stable water column, elevated temperatures and with optimal light levels leading to high cell yields during summer. In Pendant Lake the dynamics differ, with high Synechococcus sp. populations occurring at low temperatures; this suggests that the Pendant strain could be more cold-adapted or that the grazing pressure here is less than in the other lakes.

Acknowledgements. Special thanks to the following for assistance in field work, chemical and data analysis, and for general support, discussions and advice: T. Powell, J. Statham, A. Romano, J. Cavanagh, P. Berry, B. Copplestone, T. Pitman, S. McCammon, J. Nash, J. Cox, A. Davidson, S. Wright, A. McMinn, J. A. E. Gibson, T. Ross and W. F. Vincent. This research was partially supported by Australian Antarctic Science grants.

\section{LITERATURE CITED}

Agawin NSR, Duarte CM, Agusti S, McManus L (2003) Abundance, biomass and growth rates of Synechococcus sp. in a tropical coastal ecosystem (Philippines, South China Sea). Estuar Coast Shelf Sci 56:493-502

Baroli I, Do AD, Yamane T, Niyogi KK (2003) Zeaxanthin accumulation in the absence of a functional xanthophyll cycle protects Chlamydomonas reinhardtii from photooxidative stress. Plant Cell 15:992-1008

Bertrand N, Vincent WF (1994) Structure and dynamics of photosynthetic picoplankton across the saltwater transition zone of the St. Lawrence River. Can J Fish Aquat Sci 51:161-171

Bowman JP, McCammon SA, Brown MV, Nichols DS, McMeekin TA (1997) Diversity and association of psychrophilic bacteria in Antarctic sea ice. Appl Environ Microbiol 63:3068-3078

Bowman JP, McCammon SA, Brown JL, McMeekin TA (1998) Glaciecola punicea gen. nov., sp. nov. and Glaciecola pallidula gen. nov., sp. nov.: psychrophilic bacteria from Antarctic sea-ice habitats. Int J Syst Bacteriol 48: 1213-1222

Bowman JP, Rea SM, McCammon SA, McMeekin TA (2000) Diversity and community structure within anoxic sediment from marine salinity meromictic lakes and a coastal meromictic marine basin, Vestfold Hills, Eastern Antarctica. Environ Microbiol 2:227-237

Campbell L, Carpenter EJ (1986) Estimating the grazing pressure of heterotrophic nanoplankton on Synechococcus spp. using the seawater dilution and selective inhibitor techniques. Mar Ecol Prog Ser 33:121-129

Casamayor EO, Pedros-Alio C, Muyzer G, Amann R (2002) Microheterogeneity in $16 \mathrm{~S}$ ribosomal DNA-defined bacterial populations from a stratified planktonic environment is related to temporal changes and to ecological adaptations. Appl Environ Microbiol 68:1706-1714

Cohan FM (2002) What are bacterial species? Annu Rev Microbiol 56:457-487

Damsté JSS, van Dongen BE, Rijpstra WIC, Schouten S, Volkman JK, Geenevasen JAJ (2001) Novel intact glycolipids in sediments from an Antarctic lake (Ace Lake). Org Geochem 32:321-332

Ernst A, Becker S, Wollenzien UIA, Postius C (2003) Ecosystem-dependent adaptive radiations of picocyanobacteria inferred from 16S rRNA and ITS-1 sequence analysis. Microbiology (Reading) 149:217-228

Fahnenstiel GL, Patton TR, Carrick HJ, McCormick MJ (1991) Diel division cycle and growth rates of Synechococcus in Lakes Huron and Michigan. Int Rev Gesamten Hydrobiol 76:657-664

Felsenstein J (1993) PHYLIP v. 3.57c (phylogenetic inference program package). University of Washington, Seattle, WA

Franzmann PD (1996) Examination of Antarctic prokaryotic diversity through molecular comparisons. Biodiv Conserv 5:1295-1305

Fulford-Smith SP, Sikes EL (1996) The evolution of Ace Lake, Antarctica, determined from sedimentary diatom assemblages. Palaeogeogr Palaeoclimatol Palaeoecol 124:73-86

Fuller NJ, Marie D, Partensky F, Vaulot D, Post AF, Scanlan DJ (2003) Clade-specific 16S ribosomal DNA oligonucleotides reveal the predominance of a single marine Synechococcus clade throughout a stratified water column in the Red Sea. Appl Environ Microbiol 69:2430-2443

Gibson JAE (1999) The meromictic lakes and stratified marine basins of the Vestfold Hills, East Antarctica. Antarct Sci 11:175-192 
Glover HE, Morris I (1981) Photosynthetic characteristics of coccoid marine cyanobacteria. Arch Microbiol 129:42-46

Gradinger R, Lenz J (1995) Seasonal occurrence of picocyanobacteria in the Greenland Sea and central Arctic Ocean. Polar Biol 14:447-452

Hall TA (1999) A user friendly biological sequence alignment editor for Windows 95/98/NT. Nucleic Acid S Symp Ser 41:95-98

Hawes I (1990) Eutrophication and vegetation development in maritime Antarctic lakes. In: Kerry KR, Hempel G (eds) Antarctic ecosystems: ecological change and conservation. Springer-Verlag, Berlin, p 83-90

He YY, Hader DP (2002) Reactive oxygen species and UV-B: effect on cyanobacteria. Photochem Photobiol Sci 1: 729-736

Herdman M, Castenholz RW, Waterbury JB, Rippka R (2001) Form-genus XIII. Synechococcus In: Boone DR, Castenholz RW, Garrity GM (eds) Bergey's manual of systematic bacteriology, 2nd edn. Springer-Verlag, New York, p 518-522

Kirk JTO (1994) Light and photosynthesis in aquatic ecosystems, 2nd edn. Cambridge University Press, Cambridge

Larsen A, Flaten GAF, Sandaa RA, Castberg T, Thyrhaug R, Erga SR, Jacquet S, Bratbak G (2004) Spring phytoplankton bloom dynamics in Norwegian coastal waters: microbial community succession and diversity. Limnol Oceanogr 49:180-190

Laybourn-Parry J, Marchant HJ (1992) The microbial plankton of freshwater lakes in the Vestfold Hills, Antarctica. Polar Biol 12:411-416

Laybourn-Parry J, Perriss SJ (1995) The role and distribution of the autotrophic ciliate Mesodinium rubrum (Myrionecta rubrum) in three Antarctic saline lakes. Arch Hydrobiol 135:179-194

Lepesteur M, Martin JM, Fleury A (1993) A comparative study of different preservation methods for phytoplankton cell analysis by flow cytometry. Mar Ecol Prog Ser 93: 55-63

Letelier RM, Karl DM (1989) Phycoerythrin-containing cyanobacteria in surface waters of the Drake Passage during February 1987. Antarct J US 24:185-188

Liu H, Campbell L, Landry MR (1995) Growth and mortality rates of Prochlorococcus and Synechococcus measured with a selective inhibitor technique. Mar Ecol Prog Ser 116:277-287

Mackey DJ, Blanchot J, Higgins HW, Neveux J (2002) Phytoplankton abundances and community structure in the equatorial Pacific. Deep-Sea Res II 49:2561-2582

Maeda H, Kawai A, Tilzer AA (1992)The water bloom of cyanobacterial picoplankton in Lake Biwa, Japan. Hydrobiologia 248:93-103

Marchant HJ, Davidson AT, Wright SW (1987) The distribution and abundance of chroococcoid cyanobacteria in the Southern Ocean. Proc Natl Inst Polar Res (NIPR) Symp Polar Biol 1:1-9

Marmur J, Doty P (1962) Determination of the base composition of deoxyribonucleic acid from its thermal denaturation temperature. J Mol Biol 5:109-118

Merritt MV, Rosenstein SP, Loh C, Hsui-sui CR, Allen MM (1991) A comparison of the major lipid classes and fatty acid composition of marine unicellular cyanobacteria with freshwater species. Arch Microbiol 155:107-113

Moore LR, Goericke R, Chisholm SW (1995) Comparative physiology of Synechococcus and Prochlorococcusinfluence of light and temperature on growth, pigments, fluorescence and absorptive properties. Mar Ecol Prog Ser 116:259-275
Moore LR, Post AF, Rocap G, Chisholm SW (2002) Utilization of different nitrogen sources by the marine cyanobacteria Prochlorococcus and Synechococcus. Limnol Oceanogr 47:989-996

Neuer S (1992) Growth dynamics of marine Synechococcus spp. in the Gulf of Alaska. Mar Ecol Prog Ser 83: 251-262

Nichols PD, Skerratt JH, Davidson A, Burton HR, McMeekin TA (1991) Lipids of cultured Phaeocystis pouchetii: signatures for food-web, biogeochemical and environmental studies in Antarctica and the Southern Ocean. Phytochemistry 30:3209-3214

Phlips EJ, Badylak S, Lynch TC (1999) Blooms of the picoplanktonic cyanobacterium Synechococcus in Florida Bay, a subtropical inner-shelf lagoon. Limnol Oceanogr 44: $1166-1175$

Prèzelin BB (1992) Diel periodicity in phytoplankton productivity. Hydrobiologia 238:1-35

Rankin LM, Franzmann PD, McMeekin TA, Burton HR (1997) Seasonal distribution of picocyanobacteria in Ace Lake, a marine-derived Antarctic Lake. In: Battaglia B, Valencia J, Walton DWH (eds) Antarctic communities: species, structure and survival. Cambridge University Press, Cambridge, p 178-184

Ratkowsky DA, Lowry RK, McMeekin TA, Stokes AN, Chandler RE (1983) Model for bacterial culture growth rate throughout the entire biokinetic temperature range. J Bacteriol 154:1222-1226

Ratkowsky D, Olley J, Ross T (2004) Unifying temperature effects on the growth rate of bacteria and the stability of globular proteins. J Theor Biol 233:351-362

Rocap G, Distel DL, Waterbury JB, Chisholm SW (2002) Resolution of Prochlorococcus and Synechococcus ecotypes by using 16S-23S ribosomal DNA internal transcribed spacer sequences. Appl Environ Microbiol 68: $1180-1191$

Rocap G, Larimer FW, Lamerdin J, Malfatti S and 20 others (2003) Genome divergence in two Prochlorococcus ecotypes reflects oceanic niche differentiation. Nature 424: 1042-1047

Scanlan DJ, West NJ (2002) Molecular ecology of the marine cyanobacterial genera Prochlorococcus and Synechococcus. FEMS Microbiol Ecol 40:1-12

Skerratt JH, Nichols PD, Mancuso CA, James SR, Dobson SJ, McMeekin TA, Burton HR (1991) The phospholipid esterlinked fatty acid composition of members of the family Halomonadaceae and genus Flavobacterium: a chemical guide. Syst Appl Microbiol 14:8-13

Sly LI, Blackall LL, Kraat PC, Tian-Shen T, Sangkhobol V (1986) The use of second derivative plots for the determination of $\mathrm{mol} \%$ guanine plus cytosine of DNA by the thermal denaturation method. J Microbiol Methods 5: $139-156$

Sullivan MB, Waterbury JB, Chisholm SW (2003) Cyanophages infecting the oceanic cyanobacterium Prochlorococcus. Nature 424:1047-1051

Swadling KM, Gibson JAE (2000) Grazing rates of a calanoid copepod (Paralabidocera antarctica) in a continental Antarctic lake. Polar Biol 23:301-308

Tang EPY, Tremblay R, Vincent WF (1997) Cyanobacterial dominance of polar freshwater ecosystems: Are high-latitude mat-formers adapted to low temperature? J Phycol 33: $171-181$

Venkateswaran K, Shimada A, Maruyama A, Higashihara T, Sakou H, Maruyama T (1993) Microbial characteristics of Palau Jellyfish Lake. Can J Microbiol 39:506-512

Vezina S, Vincent WF (1997) Arctic cyanobacteria and limno- 
logical properties of their environment: Bylot Island, Northwest Territories, Canada $\left(73^{\circ} \mathrm{N}, 80^{\circ} \mathrm{W}\right)$. Polar Biol 17:523-534

Vincent WF (2000) Cyanobacterial diominance in the polar regions. In: Whitton BA, Potts $M$ (eds) Ecology of cyanobacteria: their diversity in time and space. Springer, New York, p 317-322

Vincent WF, Bowman JP, Rankin LM, McMeekin TA (2000) Phylogenetic diversity of picocyanobacteria in Arctic and Antarctic ecosystems. In: Bell CR, Brylinsky M, JohnsonGreen P (eds) Microbial biosystems: new frontiers, Vol 1. Atlantic Canada Society for Microbial Ecology, Halifax, p 317-322

Walker TD, Marchant HJ (1989) The seasonal occurrence of chrococcoid cyanobacteria at an Antarctic coastal site. Polar Biol 9:193-196

Waterbury JB (1992) The cyanobacteria-isolation, purification, and identification. In: Balows A, Trüper HG, Dworkin M, Harder W, Schleifer KH (eds) The prokaryotes, 2nd edn, Vol II. Springer-Verlag, New York, p 2058-2078

Wayne LG, Brenner DJ, Colwell RR and 9 others (1987) Inter-

Editorial responsibility: Otto Kinne (Editor-in-Chief),

Oldendorf/Luhe, Germany national Committee on Systematic Bacteriology. Report of the ad hoc committee on reconciliation of approaches to bacterial systematics. Int J Syst Bacteriol 37:463-464

White DC, Davis WM, Nickels JS, King JD, Bobbie RJ (1979) Determination of the sedimentary microbial biomass by extractable lipid phosphate. Oecologia 40:51-62

Wilmotte A, Demonceau C, Goffart A, Hecq JH, Demoulin V, Crossley AC (2002) Molecular and pigment studies of the picophytoplankton in a region of the Southern Ocean $\left(42-54^{\circ} \mathrm{S}, 141-144^{\circ} \mathrm{E}\right)$ in March 1998. Deep-Sea Res II 49: $3351-3363$

Wright SW, Jeffrey SW, Mantoura RFC, Llewellyn CA, Bjornland T, Repeta D, Welschmeyer N (1991) Improved HPLC method for analysis of chlorophylls and carotenoids from marine phytoplankton. Mar Ecol Prog Ser 77:183-196

Xiuren N, Vaulot D (1992) Estimating Synechococcus spp. growth rates and grazing pressure by heterotrophic nanoplankton in the English Channel and the Celtic Sea. Acta Oceanol Sin 11:255-273

ZoBell CE (1946) Marine microbiology. Chronica Botanica, Waltham, MA

Submitted: May 19, 2004; Accepted: October 19, 2004

Proofs received from author(s): April 7, 2005 